\title{
Effect of Solid State Fermentation Medium Optimization on Pleurotus ostreatus Laccase Production
}

\author{
Nataša Belšak Šel, ${ }^{1, *}$ Andrej Gregori, ${ }^{2,3}$ Maja Leitgeb, ${ }^{4}$ \\ Dušan Klinara ${ }^{1}$ and Štefan Čelan ${ }^{1}$ \\ ${ }^{1}$ Scientific Research Centre Bistra Ptuj, Slovenski trg 6, 2250 Ptuj, Slovenia \\ ${ }^{2}$ Institute for Natural Science, Ulica bratov Učakar 108, 1000 Ljubljana, Slovenia \\ ${ }^{3}$ MycoMedica d. o. o., Podkoren 72, 4280 Kranjska Gora, Slovenia \\ ${ }^{4}$ University of Maribor, Faculty of Chemistry and Chemical Engineering, Laboratory for Separation Processes \\ and Production Design, Smetanova 17, 2000 Maribor, Slovenia \\ * Corresponding author: E-mail: natasa.belsak@bistra.si, \\ Tel: +3862 74802 58, Fax: +38627480260
}

Received: 18-06-2015

\begin{abstract}
The objective of this work was to increase laccase production by Pleurotus ostreatus PLAB through culture medium optimization using solid-state culture conditions. Increased laccase activity was obtained through the design of experiments (DOE) using the Taguchi orthogonal array (OA). Seven factors, viz. lignocellulose, glucose, yeast extract, peptone, $\mathrm{KH}_{2} \mathrm{PO}_{4}, \mathrm{MgSO}_{4} \cdot 7 \mathrm{H}_{2} \mathrm{O}$ and $\mathrm{MnSO}_{4} \cdot \mathrm{H}_{2} \mathrm{O}$ at three levels and $\mathrm{pH}$ at two levels with OA layout of $\mathrm{L} 18\left(2^{1} \times 3^{7}\right)$ were selected for the proposed experimental design using Minitab 17 software. Data analysis showed that lignocellulose (20\%) and glucose $\left(10 \mathrm{~g} \mathrm{~L}^{-1}\right)$ had a positive effect, whereas $\mathrm{KH}_{2} \mathrm{PO}_{4}, \mathrm{MgSO}_{4} \cdot 7 \mathrm{H}_{2} \mathrm{O}$ and $\mathrm{MnSO}_{4} \cdot \mathrm{H}_{2} \mathrm{O}$ did not have a significant effect on laccase production. Taguchi OA analysis showed that $\mathrm{pH} 6$, lignocellulose $20 \%$, glucose $10 \mathrm{~g} \mathrm{~L}^{-1}$, yeast extract $6 \mathrm{~g} \mathrm{~L}^{-1}$, peptone $15 \mathrm{~g} \mathrm{~L}^{-1}, \mathrm{KH}_{2} \mathrm{PO}_{4} 3 \mathrm{~g} \mathrm{~L}^{-1}, \mathrm{MgSO}_{4} \cdot 7 \mathrm{H}_{2} \mathrm{O} 0.5 \mathrm{~g} \mathrm{~L}^{-1}$ and $\mathrm{MnSO}_{4} \cdot \mathrm{H}_{2} \mathrm{O} 0.1 \mathrm{~g} \mathrm{~L}^{-1}$ were the optimal conditions to maximize laccase production. The model predicted a $30.37 \mathrm{U} \mathrm{g}^{-1}$ dry wt., which agreed with the experimentally obtained laccase activity $29.15 \mathrm{U} \mathrm{g}^{-1}$ dry wt. at optimal conditions.
\end{abstract}

Keywords: Taguchi method (DOE); Orthogonal array (OA); Optimization; Pleurotus ostreatus; Laccase production; Solid state fermentation

\section{Introduction}

Laccases (EC 1.10.3.2; benzenediol: oxygen oxidoreductase) are blue multi-copper oxidases with ability to catalyse the oxidation of a wide variety of organic compounds such as mono-, di- and polyphenols, aminophenols, methoxyphenols, aromatic amines and ascorbic acid. ${ }^{1,2}$ Beside their biotechnological potential in diverse fields of industrial applications related to bioremediation; including delignification of lignocellulosic, colour removal and detoxification of industrial dyes, bioremediation of xenobiotic compounds, pesticides, explosives, wastewater treatment, and treatment of other pollutants such as polycyclic aromatic hydrocarbons (PAHs). ${ }^{2,3}$ Efficient laccase production requires combinations of several fac- tors, such as an easy to grow fungal strain with the ability to secrete specific enzymes, appropriate culture media, an addition of inducers and appropriately selected cultivation system. In some cases, the influence of single factor on the laccase production has been studied, but mostly different parameters in production media composition have been optimized. ${ }^{4,5,6,7,8,9}$ It is known that fungal laccases production, particularly that of white - rot basidiomycetes, can be affected by type and concentration of carbon and nitrogen source and also by the presence of copper and organic compounds which function as inducers of laccase activity. ${ }^{10,11,12,13}$

However, the laccase production by basidiomycetes has been reported in solid state fermentation (SSF) ${ }^{14,15}$ as well as in submerged liquid fermentation ( $\mathrm{SmF})$ sys- 
tem. ${ }^{16,17}$ SSF is generally defined as the growth of microorganisms on solid materials in the absence or near absence of free water. It is also treated as an adequate method for filamentous fungi cultivation and lignocellulolytic enzyme production. SSF provides growth conditions similar to natural habitats and thus in comparison to submerged fermentation enables higher productivity of certain enzymes. ${ }^{18}$ Although there are some disadvantages regarding SSF, such as long retention time and difficulties of fermentation parameters detection, SSF is highly attractive and alternative process due to its low capital cost using food and agricultural wastes as substrates. Beside this SSF provides a high concentration of products and the simple products isolations techniques. ${ }^{19,20}$ Agro-industrial wastes as substrate for fermentative processes are easily available, rich in carbon and often present disposal problems. ${ }^{21,22}$

The DOE technique helps to study many factors (variables) simultaneously and more economically. Through studying the effects of individual factors on the results, the best factor combination can be determined. When applied to product or process design, this technique helps to search for the best design among many alternatives. It can also be used to solve scientific problems whose solution lies in the proper combination of ingredients (factors or variables) rather than innovations or a single identifiable cause. ${ }^{23}$ The Taguchi method involves reducing the variation in a process through the robust design of experiments. This is a method for designing experiments to investigate how different parameters affect the mean and variance of a process performance characteristic defining how well the process functions. The experimental design proposed by Taguchi involves use of orthogonal arrays in order to organize the parameters affecting the process and the levels at which they should be varied; it allows for the collection of the necessary data to determine which factors affect product quantity the most, with a minimum amount of experiments, thus saving time and resources. Analysis of variance on the collected data from Taguchi DOE can be used to select new parameter values in order to optimize the performance characteristic. ${ }^{24}$ There are two types of factors affecting product or process. First are control factors and the second are noise factors. Control factors (process temperature or incubation time) are easily controlled, while noise factors are difficult or impossible to control (outside temperature, mycelium growth rate). Signal to noise analysis $(\mathrm{S} / \mathrm{N})$ is a preferred parameter setting where factor levels maximizing the appropriate $\mathrm{S} / \mathrm{N}$ ratio, are optimal. There are three different categories of the performance characteristic in the $\mathrm{S} / \mathrm{N}$ ratio analysis:

Smaller the better (enabling system response as small as possible):

$$
-10 \log \left[\frac{1}{n} \sum_{i=1}^{n} y_{i}^{2}\right]
$$

Nominal is the best (reducing variability around the target):

$$
10 \log \left[\frac{\bar{y}^{2}}{s^{2}}\right]
$$

Larger the better (enabling as large as possible system response):

$$
-10 \log \left[\frac{1}{n} \sum_{i=1}^{n} \frac{1}{y_{i}^{2}}\right]
$$

Where $\bar{y}$ is the average of observed data, $s$ is the variance of $\mathrm{y}, \mathrm{n}$ is being a repeated number of experiments and $\mathrm{y}$ is being the observed data. ${ }^{25}$

The purpose of this work was optimization of SSF media composition for $P$. ostreatus laccase production using DOE. Experimental setup was based on an orthogonal array layout of L18 $\left(2^{1} \times 3^{7}\right)$, selecting one factor $(\mathrm{pH})$ with two levels and the remaining seven factors (lignocellulose, glucose, yeast extract, peptone, $\mathrm{KH}_{2} \mathrm{PO}_{4}$, $\mathrm{MgSO}_{4} \cdot 7 \mathrm{H}_{2} \mathrm{O}$ and $\mathrm{MnSO}_{4} \mathrm{H}_{2} \mathrm{O}$ ) with three levels.

\section{Materials and Methods}

\section{1. Organisms and Inoculum Preparation}

P. ostreatus strain PLAB was obtained from the fungal culture collection at the Department of Wood Science and Technology, Biotechnical Faculty, University of Ljubljana, Slovenia. It was cultivated on potato dextrose agar (PDA) plates at $24{ }^{\circ} \mathrm{C}$ for 7 days in dark and later stored at $4{ }^{\circ} \mathrm{C}$ with subsequent transfers every 4 weeks. PDA plates overgrown with mycelium were cut with cork borer to acquire $6 \mathrm{~mm}$ in diameter mycelium culture discs and used for substrate inoculation.

\section{2. Solid State Fermentation (SSF) Experiment and Enzyme Extraction}

Experiments were carried out in solid state culture using wheat bran (WB) as a basic substrate alone or supplemented with lignocellulose biomass (LB). The proportion of LB is specified in Table 1. Five grams of a substrate were transferred into $250 \mathrm{~mL}$ Erlenmeyer flasks and moistened with a specific amount of mineral salt medium to reach the final moisture content of $80 \%$. There was no free liquid phase in solid state culture medium. All nutrients from mineral salt medium have been fixed in the solid matrix. The mineral salt medium contains glucose, yeast extract, peptone, $\mathrm{KH}_{2} \mathrm{PO}_{4}, \mathrm{MgSO}_{4} \cdot 7 \mathrm{H}_{2} \mathrm{O}$ and $\mathrm{Mn}$ $\mathrm{SO}_{4} \cdot \mathrm{H}_{2} \mathrm{O}$. Concentration of mineral salt medium has been varied between individual experiments depending on the Taguchi OA experimental design specified in Table 1. WB was obtained from a local mill. LB was obtained from local collection centre for separately collected waste 
fractions and consisted of wood biomass, containing tree and shrub pruning. Besides this a large part of LB contained grass cuttings, hedge trimmings, old flowers, and leaves. LB used in this study was a mixture of 6 fractions obtained at different year season and with different ratios of individual lignocellulose parts. All substrates were dried at $60{ }^{\circ} \mathrm{C}$ overnight and chopped in pieces of $0.2-0.5 \mathrm{~cm}$. The initial $\mathrm{pH}$ of the medium was adjusted to 5.0 or 6.0 by an addition of $2 \mathrm{M} \mathrm{HCl}$ or $2 \mathrm{M} \mathrm{NaOH}$ prior to sterilization. The flasks were equipped with cotton stoppers and autoclaved at $121{ }^{\circ} \mathrm{C}$ for $25 \mathrm{~min}$ and after sterilization inoculated with three $6 \mathrm{~mm}$ diameter discs of PDA overgrown with mycelia. Incubation of substrates was carried out under static conditions at $28 \pm 1{ }^{\circ} \mathrm{C}$ in the dark. The flasks were incubated at an 8-day interval.

After incubation, $40 \mathrm{~mL}$ of $0.05 \mathrm{M}$ sodium citrate buffer ( $\mathrm{pH} 4.8$ ) was added to each flask and the flasks were kept on a rotary shaker at $150 \mathrm{rpm}$ and room temperature. After $1.5 \mathrm{~h}$ of incubation, the slurry was filtered through cheesecloth and squeezed to maximize the enzyme extraction. The filtered solution was centrifuged for 20 min at $3000 \mathrm{rpm}$ and $4{ }^{\circ} \mathrm{C}$ to remove debris and filtered using $1.2 \mu \mathrm{m}$ glass microfiber filters (Whatman ${ }^{\circledR} \mathrm{GF} / \mathrm{C}$ ). The supernatant was used for enzyme activity assessment. Extracts were kept at $4{ }^{\circ} \mathrm{C}$ until analysed (less than $24 \mathrm{~h}$ ). For future analysis, the crude enzyme extracts were stored in a freezer until use.

\section{3. Laccase Activity Assay}

Laccase activity in the crude enzyme extract was measured by monitoring the oxidation of 2,2-azino-bis (3-ethybenzthiazoline-6 sulphonic acid) (ABTS). ${ }^{26}$ The reaction mixture contained $0.4 \mathrm{~mL}$ of $1 \mathrm{mM}$ ABTS, $1.2 \mathrm{~m}$ $\mathrm{L}$ of $0.1 \mathrm{M}$ sodium acetate buffer ( $\mathrm{pH} 5$ ) and $0.8 \mathrm{~mL}$ crude enzyme extract; the reaction was carried out during $1 \mathrm{~min}$. The crude enzyme extract was added into the reaction mixture just before the absorbance measurements. Oxidation of ABTS was monitored spectrophotometrically by determining absorbance at $420 \mathrm{~nm}\left(\varepsilon=36000 \mathrm{M}^{-1} \mathrm{~cm}^{-1}\right)$ using UV-Vis spectrophotometer (Hach Lange DR 2800). One unit of laccase activity is defined as the amount of enzyme oxidizing $1 \mu \mathrm{mol}$ of ABTS per minute under standard assay conditions. The enzyme activity is expressed in $\mathrm{U} \mathrm{g}^{-1}$ dry weight of substrate $\left(\mathrm{U}=\mu \mathrm{mol} \mathrm{ml}^{-1} \mathrm{~min}^{-1}\right)$.

\section{4. Taguchi Orthogonal Matrix Method}

Optimization methodology of Taguchi method with multiple performance characteristics includes various steps. The first step was to identify the performance characteristics and select process parameters to be evaluated. The next step was to determine the number of levels for the process parameters and select the appropriate orthogonal array and assignment of process parameters to the orthogonal array. In the present case, L18 orthogonal array (which indicates 18 experimental trials) was conducted. All factors have been assigned with three levels except $\mathrm{pH}$ (which was assigned with two levels) with L18 $\left(2^{1} \times\right.$ $3^{7}$ ) layout (Table 1 and Table 2). Orthogonal array arrangement of the experimental plan has been conducted in the next step. SSF experiments were performed for laccase production. Experimental data analysis and performance prediction were the next steps. Obtained experimental data was processed in the Minitab 17 software using S/N ratio and ANOVA. S/N ratio characteristic for this study was »Larger the better « since a maximum of laccase production was desired. Equation (3) was applied to obtain $\mathrm{S} / \mathrm{N}$ ratio of every experiment run. In order to validate the methodology, optimal process parameters were verified through the confirmation experiment. ${ }^{27}$

Table 1: Factors and their levels in the experimental design

\begin{tabular}{clccc}
\hline Serial no. & Factors & Level 1 & Level 2 & Level 3 \\
\hline 1 & $\mathrm{pH}$ & 5 & 6 & \\
2 & $\mathrm{LB}(\%)$ & 0 & 10 & 20 \\
3 & glucose $\left(\mathrm{g} \mathrm{L}^{-1}\right)$ & 5 & 10 & 15 \\
4 & yeast extract $\left(\mathrm{g} \mathrm{L}^{-1}\right)$ & 2 & 4 & 6 \\
5 & peptone $\left(\mathrm{g} \mathrm{L}^{-1}\right)$ & 5 & 10 & 15 \\
6 & $\mathrm{KH}_{2} \mathrm{PO}_{4}\left(\mathrm{~g} \mathrm{~L}^{-1}\right)$ & 1 & 2 & 3 \\
7 & $\mathrm{MgSO}_{4} \cdot 7 \mathrm{H}_{2} \mathrm{O}\left(\mathrm{g} \mathrm{L}^{-1}\right)$ & 0.5 & 1 & 1.5 \\
8 & $\mathrm{MnSO}_{4} \cdot \mathrm{H}_{2} \mathrm{O}\left(\mathrm{g} \mathrm{L}^{-1}\right)$ & 0.075 & 0.1 & 0.125 \\
\hline
\end{tabular}

\section{Results and Discussion}

\section{1. Effect of Parameters on Laccase Activity}

Culture conditions optimization by preliminary study indicates that medium containing WB mix with LB showed the highest laccase production. A preliminary study was conducted for studying the ability of production exo-glucanase, endo-glucanase, $\beta$-glucosidase, xylanase and laccase of white rot basidiomycete $P$. ostreatus PLAB on six different solid substrate combinations moistened with mineral salt medium which had following composition $\left(\mathrm{g} \mathrm{L}^{-1}\right.$ : yeast extract 2.0, peptone 5.0, $\mathrm{MnSO}_{4} \cdot \mathrm{H}_{2} \mathrm{O}$ $0.075, \mathrm{KH}_{2} \mathrm{PO}_{4} 1.0, \mathrm{MgSO}_{4} \cdot 7 \mathrm{H}_{2} \mathrm{O} 0.5$ ). The mycelium of $P$. ostreatus was inoculated on $\mathrm{WB}$ and beech sawdust substrates, which were mixed in different ratios with LB. In addition, an effect of incubation time on lignocellulytic enzymes activities was investigated. The results indicated low activity for cellulytic enzymes and xylanase for all six investigated substrates while the laccase activities reached the highest value (17.35 $\mathrm{U} \mathrm{g}^{-1}$ dry wt) in comparison to other enzymes. The highest laccase activities were determined on a substrate containing WB and LB in ratio 4:1. Results also indicate maximum laccase activity on 8 days of cultivation, when the entire surface of culture medium was covered with the mycelium mat. Since the activity of laccase is associated with morphogenesis it is increased 
with mycelial growth, peaked at maximum growth and thereafter decreased rapidly which is in agreement with the Rana and Rana. ${ }^{28}$ Statistical optimization of SSF factors for maximizing laccase production was attempted using eight fermentation factors and their selected levels (Table 1) based on our preliminary studies. In order to assess the effect of the process parameters on SSF laccase production, experiments were conducted using Taguchi L18 OA (Table 2). SSF experiments conducted with the designed experimental condition showed a significant variation in laccase activity (Table 2). The main effect of selected factors on the laccase production, along with its interaction at the assigned levels is shown in Table $3 . \mathrm{MgSO}_{4} \cdot 7 \mathrm{H}_{2} \mathrm{O}$ shows the highest effect at level 1 , whereas $\mathrm{pH}$, glucose, and $\mathrm{MnSO}_{4} \cdot \mathrm{H}_{2} \mathrm{O}$ have a higher effect at level 2. At level 3, the major effect was expressed by $\mathrm{LB}$, yeast extract, peptone, and $\mathrm{KH}_{2} \mathrm{PO}_{4}$. The highest effect indicates LB at level 3. The lignin is the key factor that may influence the difference found in the laccase activity. observed that the addition of lignin to the culture medium had a strong positive influence on the production of laccase by $P$. ostreatus. The obtained result shows that laccase yield was higher at $\mathrm{pH} 6$ than at pH 5 (Table 3) what is in agreement with the Mikiashavili et al. ${ }^{29}$ and Periasamy et al. ${ }^{30}$ who reached maximum amount of laccase enzyme at the initial $\mathrm{pH}$ of the medium of 6 . The $\mathrm{pH}$ is one of the main operational parameter influence the metabolic activity of the organism rather strongly. ${ }^{31}$ As reported by Moharib et al. ${ }^{32}$ solid wheat bran added as substrate induces higher laccase activity. Agro-waste materials which are majority composed of lignin, cellulose and hemicellulose serves as a major source of carbon and energy for Pleurotus species cultivation. ${ }^{33}$ A maximum laccase activity production level of $26.00 \pm 0.98 \mathrm{U} \mathrm{g}^{-1}$ of dry weight ( $\mathrm{U} \mathrm{g}^{-1}$ dry wt.) was achieved at trial no. 17, as shown in Table 2.

The difference between level 2 and level 1 (L2 L1) of each factor (Table 3), indicates the relative influence of the effect. The larger the difference, the stronger is the influence. It can be seen from Table 3, that among the factors studied, glucose showed a stronger influence (L2 - L1) when compared to other factors. Increa-

Table 2: Experimental design using Taguchi L18 orthogonal array

\begin{tabular}{|c|c|c|c|c|c|c|c|c|c|}
\hline Experiment no. & 1 & \multicolumn{6}{|c|}{ Column (factors) } & 8 & $\begin{array}{l}\text { Laccase activity } \\
\text { (U g g dry wt.) }\end{array}$ \\
\hline 1 & 1 & 1 & 1 & 1 & 1 & 1 & 1 & 1 & $10.90 \pm 0.36$ \\
\hline 2 & 1 & 1 & 2 & 2 & 2 & 2 & 2 & 2 & $17.79 \pm 0.44$ \\
\hline 3 & 1 & 1 & 3 & 3 & 3 & 3 & 3 & 3 & $16.49 \pm 1.39$ \\
\hline 4 & 1 & 2 & 1 & 1 & 2 & 2 & 3 & 3 & $12.47 \pm 1.86$ \\
\hline 5 & 1 & 2 & 2 & 2 & 3 & 3 & 1 & 1 & $19.42 \pm 0.14$ \\
\hline 6 & 1 & 2 & 3 & 3 & 1 & 1 & 2 & 2 & $14.66 \pm 0.76$ \\
\hline 7 & 1 & 3 & 1 & 2 & 1 & 3 & 2 & 3 & $20.21 \pm 0.72$ \\
\hline 8 & 1 & 3 & 2 & 3 & 2 & 1 & 3 & 1 & $24.98 \pm 0.63$ \\
\hline 9 & 1 & 3 & 3 & 1 & 3 & 2 & 1 & 2 & $21.80 \pm 0.80$ \\
\hline 10 & 2 & 1 & 1 & 3 & 3 & 2 & 2 & 1 & $17.23 \pm 0.26$ \\
\hline 11 & 2 & 1 & 2 & 1 & 1 & 3 & 3 & 2 & $18.38 \pm 0.36$ \\
\hline 12 & 2 & 1 & 3 & 2 & 2 & 1 & 1 & 3 & $16.35 \pm 1.39$ \\
\hline 13 & 2 & 2 & 1 & 2 & 3 & 1 & 3 & 2 & $16.39 \pm 0.41$ \\
\hline 14 & 2 & 2 & 2 & 3 & 1 & 2 & 1 & 3 & $20.95 \pm 1.86$ \\
\hline 15 & 2 & 2 & 3 & 1 & 2 & 3 & 2 & 1 & $14.01 \pm 1.86$ \\
\hline 16 & 2 & 3 & 1 & 3 & 2 & 3 & 1 & 2 & $24.73 \pm 0.68$ \\
\hline 17 & 2 & 3 & 2 & 1 & 3 & 1 & 2 & 3 & $26.00 \pm 0.98$ \\
\hline 18 & 2 & 3 & 3 & 2 & 1 & 2 & 3 & 1 & $20.06 \pm 1.22$ \\
\hline
\end{tabular}

Table 3: Response table for mean values ("Larger is better")

\begin{tabular}{|c|c|c|c|c|c|c|}
\hline Serial no. & Factors & Level 1 & Level 2 & Level 3 & Rank & L2 - L1 \\
\hline 1 & $\mathrm{pH}$ & 17.64 & 19.34 & & 5 & 1.70 \\
\hline 2 & LB $(\%)$ & 16.19 & 16.31 & 22.96 & 1 & 0.12 \\
\hline 3 & glucose $\left(\mathrm{g} \mathrm{L}^{-1}\right)$ & 16.99 & 21.25 & 17.23 & 2 & 4.26 \\
\hline 4 & yeast extract $\left(\mathrm{g} \mathrm{L}^{-1}\right)$ & 17.26 & 18.37 & 19.84 & 3 & 1.11 \\
\hline 5 & peptone $\left(\mathrm{g} \mathrm{L}^{-1}\right)$ & 17.52 & 18.39 & 19.55 & 4 & 0.87 \\
\hline 6 & $\mathrm{KH}_{2} \mathrm{PO}_{4}\left(\mathrm{~g} \mathrm{~L}^{-1}\right)$ & 18.21 & 18.38 & 18.88 & 8 & 0.17 \\
\hline 7 & $\mathrm{MgSO}_{4} \cdot 7 \mathrm{H}_{2} \mathrm{O}\left(\mathrm{g} \mathrm{L}^{-1}\right)$ & 19.02 & 18.32 & 18.13 & 7 & -0.70 \\
\hline 8 & $\mathrm{MnSO}_{4} \cdot \mathrm{H}_{2} \mathrm{O}\left(\mathrm{g} \mathrm{L}^{-1}\right)$ & 17.77 & 18.96 & 18.74 & 6 & 1.19 \\
\hline
\end{tabular}


ses in the concentration of factors such as $\mathrm{pH}, \mathrm{LB}$, yeast extract, peptone and $\mathrm{KH}_{2} \mathrm{PO}_{4}$ resulted in increased enzyme production. In the case of glucose and $\mathrm{MnSO}_{4} \cdot \mathrm{H}_{2} \mathrm{O}$, the laccase yield was higher up to level 2, but a subsequent increase in the concentration (level 3) decreased the laccase yield. In the case of $\mathrm{MgSO}_{4} \cdot 7 \mathrm{H}_{2} \mathrm{O}$ the laccase yield was higher at level 1 and subsequent increase in the concentration to level 2 and 3 resulted in decreased laccase yield.

\section{2. Analysis of Variance (ANOVA)}

The contribution of individual factors is the key for the control of SSF laccase production enhancement. In this approach, ANOVA was used to analyse the results of the OA experiment and to determine the variation according to each factor. ANOVA with the contribution percentage of each factor with interactions is shown in Table 4. The analysis was carried out with a significance level of $\alpha=0.05$ (confidence level of $95 \%$ ). Thus, the P - value greater than 0.05 , the contribution of that factor is insignificant or negligible. Results indicate that $\mathrm{KH}_{2} \mathrm{PO}_{4}$,
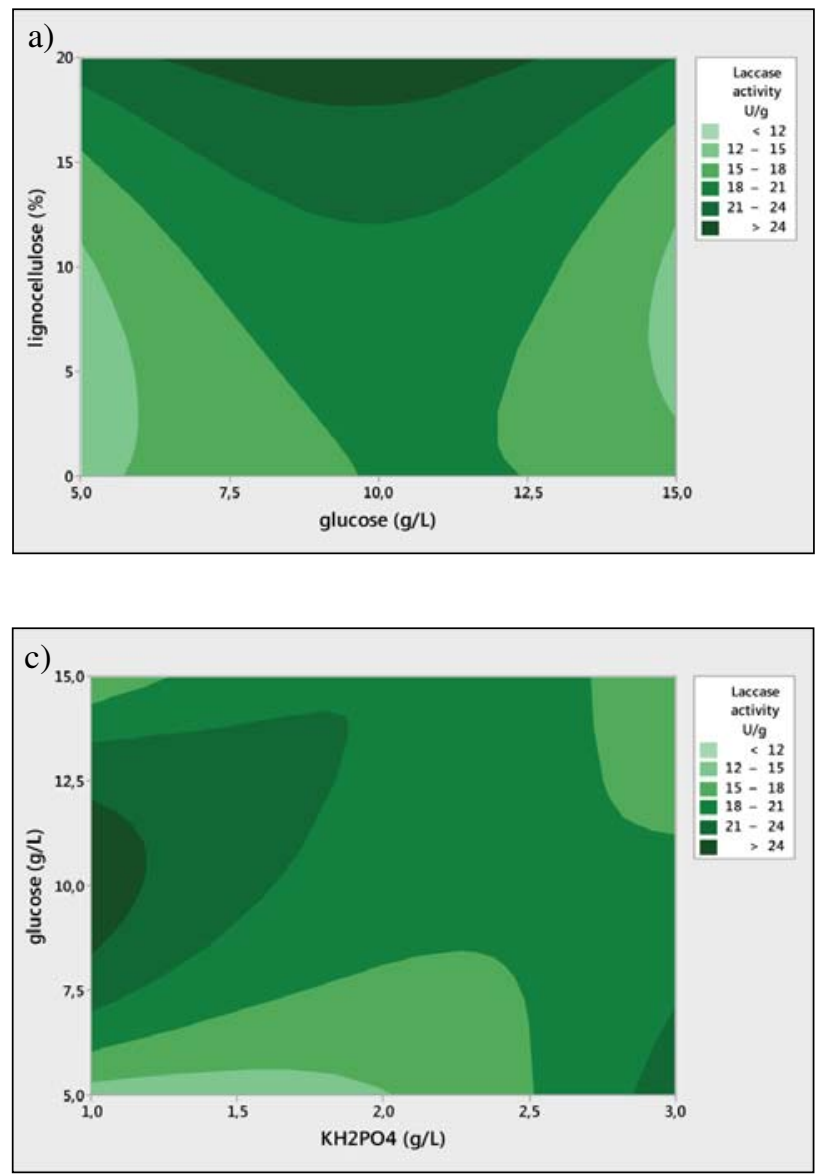

$\mathrm{MgSO}_{4} \cdot 7 \mathrm{H}_{2} \mathrm{O}$ and $\mathrm{MnSO}_{4} \cdot \mathrm{H}_{2} \mathrm{O}$ had a negligible effect on laccase production.

The percentage contribution was calculated for each individual factor by the ratio of a pure sum to the total sum of the squares. The most influenced factor was the LB, accounting for $59.24 \%$ of the overall experimental data variance, followed by glucose $(22.61 \%)$, yeast extract $(6.58 \%), \mathrm{pH}(4.30 \%)$, peptone $(4.10 \%)$, $\mathrm{MnSO}_{4} \cdot \mathrm{H}_{2} \mathrm{O}(1.59 \%), \mathrm{MgSO}_{4} \cdot 7 \mathrm{H}_{2} \mathrm{O}(0.87 \%)$ and $\mathrm{KH}_{2} \mathrm{PO}_{4}(0.47 \%)$. As can be seen from the results, LB and glucose has the major contribution to the laccase production compared to other factors involved in the experiment. Besides, $\mathrm{MnSO}_{4} \cdot \mathrm{H}_{2} \mathrm{O}, \mathrm{MgSO}_{4} \cdot 7 \mathrm{H}_{2} \mathrm{O}$ and $\mathrm{KH}_{2} \mathrm{PO}_{4}$ showed the lowest contribution, which is in accordance with $\mathrm{P}$ - value for these factors, demonstrating their insignificant effect on laccase production. P. ostreatus laccase production was significantly influenced by the concentration of carbon and nitrogen sources. Other factors reported in the literature inducing laccase production by $P$. ostreatus in SSF are yeast extract, copper sulfate and ferulic acid, using sugarcane bagasse as a substrate. ${ }^{34}$
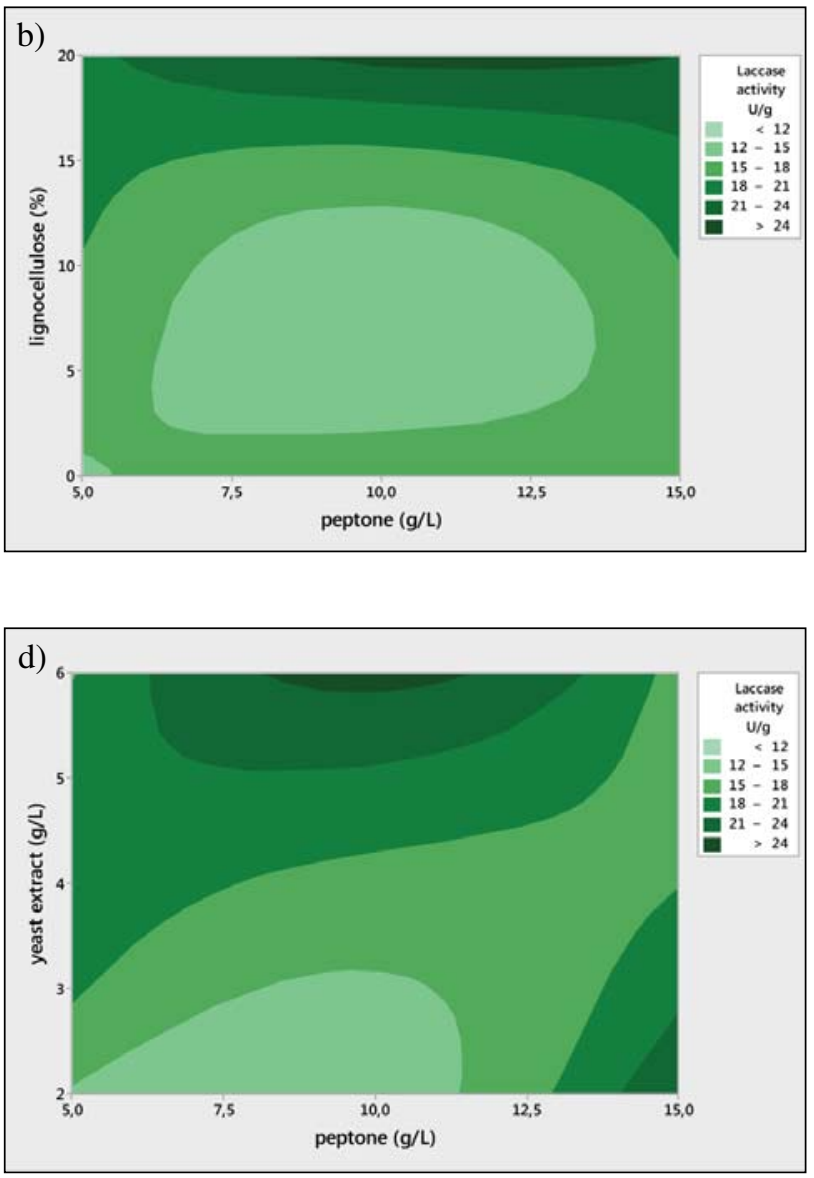

Figure 1: Contour plots of the interactive effects of: (a) LB and glucose, (b) LB and peptone, (c) glucose and $\mathrm{KH}_{2} \mathrm{PO}{ }_{4}$ and (d) yeast extract and peptone on laccase activity. 
Table 4: Analysis of variance means (ANOVA)

\begin{tabular}{|c|c|c|c|c|c|c|}
\hline Source & DF & Adj. SS & Adj. MS & F-value & P-value & $\begin{array}{c}\text { Percentage } \\
\text { contribution }(\%)\end{array}$ \\
\hline$\overline{\mathrm{pH}}$ & 1 & 13.066 & 13.0662 & 34.20 & 0.028 & 4.30 \\
\hline LB $(\%)$ & 2 & 180.159 & 90.0795 & 235.76 & 0.004 & 59.24 \\
\hline glucose $\left(\mathrm{g} \mathrm{L}^{-1}\right)$ & 2 & 68.773 & 34.3864 & 90.00 & 0.011 & 22.61 \\
\hline yeast extract $\left(\mathrm{g} \mathrm{L}^{-1}\right)$ & 2 & 20.010 & 10.0051 & 26.19 & 0.037 & 6.58 \\
\hline peptone $\left(\mathrm{g} \mathrm{L}^{-1}\right)$ & 2 & 12.458 & 6.2289 & 16.30 & 0.058 & 4.10 \\
\hline $\mathrm{KH}_{2} \mathrm{PO}_{4}\left(\mathrm{~g} \mathrm{~L}^{-1}\right)$ & 2 & 1.435 & 0.7175 & 1.88 & 0.347 & 0.47 \\
\hline $\mathrm{MgSO}_{4} \cdot 7 \mathrm{H}_{2} \mathrm{O}\left(\mathrm{g} \mathrm{L}^{-1}\right)$ & 2 & 2.633 & 1.3166 & 3.45 & 0.225 & 0.87 \\
\hline $\mathrm{MnSO}_{4} \cdot \mathrm{H}_{2} \mathrm{O}\left(\mathrm{g} \mathrm{L}^{-1}\right)$ & 2 & 4.831 & 2.4155 & 6.32 & 0.137 & 1.59 \\
\hline Error & 2 & 0.764 & 0.3821 & & & 0.25 \\
\hline Total & 17 & 304.129 & & & & \\
\hline
\end{tabular}

Figure 1 represents the interaction of LB and glucose, LB and peptone, yeast extract and peptone on laccase production rate, as well as the effect of glucose and $\mathrm{KH}_{2} \mathrm{PO}_{4} \cdot 2 \mathrm{D}$ contour plots show the interrelationships between two tested variables and the relationship between responses and experimental levels of each variable. Different shapes of contour plots indicated a different interaction between two variables, darker green regions indicating higher laccase activity. Laccase activity affected by LB and glucose is seen in Figure 1a. It was obvious that the laccase activity reached the maximum value at $10 \mathrm{~g}$ $\mathrm{L}^{-1}$ glucose and $20 \% \mathrm{LB}$ concentration. This is in accordance with optimum culture conditions presented in Table 5 , with LB at level $3(20 \%)$ having the major contribution on laccase activity, followed by glucose at level $2(10 \mathrm{~g}$ $\left.\mathrm{L}^{-1}\right)$. A possible explanation for this stimulatory effect of lignin and glucose on laccase production could be in lignin composition and proper glucose concentration. Laccase production could be stimulated by the presence of a wide variety of inducing substrates which are present in lignin conformation (aromatic compounds) such as ferulic acid, 2,5-xylidine, p-anisidine and veratryl alcohol. Lignin is known as a natural inducer for laccase formation. ${ }^{35}$ Glucose is a readily utilizable substrate which promotes biomass production and fungal growth within solid growth medium. A higher glucose concentration could lead in fungal growth repression as fungi react with the energy-saving response in such cases. ${ }^{36}$ The combination of glucose and lignin at proper concentration contributes to laccase formation. Figure $1 \mathrm{~b}$ presents interaction between LB and peptone, indicating the highest response to laccase activity at $20 \% \mathrm{LB}$ and $12.5 \mathrm{~g} \mathrm{~L}^{-1}$ peptone. Although glucose and $\mathrm{KH}_{2} \mathrm{PO}_{4}$ show a low contribution to the laccase activity, Figure 1c shows an interaction between glucose and $\mathrm{KH}_{2} \mathrm{PO}_{4}$ indicating high laccase activity at concentration $10 \mathrm{~g} \mathrm{~L}^{-1}$ glucose and $1 \mathrm{~g} \mathrm{~L}^{-1} \mathrm{KH}_{2} \mathrm{PO}_{4}$, respectively. In addition Figure $1 \mathrm{~d}$ indicates high laccase activity for yeast extract $\left(6 \mathrm{~g} \mathrm{~L}^{-1}\right)$ and peptone $\left(10 \mathrm{~g} \mathrm{~L}^{-1}\right)$, despite the fact that yeast extract and peptone individually indicated a low contribution to laccase activity.

\section{3. Confirmation Test}

In order to validate the expected result, a confirmation test with optimal conditions (Table 5) obtained from Taguchi method was performed. The SSF of $P$. ostreatus at the optimal combination of parameters and their levels was performed and the final laccase activity at 8 days of incubation was determined. The predicted value for laccase production using Minitab software was $30.37 \mathrm{U} \mathrm{g}^{-1}$ dry wt. Table 6 shows a comparison between the predicted value of total laccase activity at the optimum condition and the experimental value. Laccase activity 29.15 $\mathrm{U} \mathrm{g}^{-1}$ dry wt. obtained through confirmation experiments are within the $95 \%$ of confidence level and therefore in correlation with predicted result. Membrillo et al. ${ }^{14}$ have reported a maximal laccase activity production of $0.04 \mathrm{U}$ $\mathrm{g}^{-1}$ dry wt. at the 8 days of $P$. ostreatus IE8 SSF on sugarcane bagasse with the addition of ammonium sulphate. A maximum laccase activity production level of $15 \mathrm{U}$ $\mathrm{g}^{-1}$ dry wt. was achieved at the third to fourth day of $P$. ostreatus SSF on tomato pomace ${ }^{37}$. Isikhuemhen and Mikiashvilli ${ }^{38}$ reported the highest laccase activity of 164.6 $\mathrm{U} \mathrm{g}^{-1}$ of P. ostreatus MBFBL400 on SSF of wheat straw and solid waste from anaerobic digestion of litter mixture. Our result are consistent with the findings of

Table 5: Optimum culture conditions and their contribution

\begin{tabular}{clccc}
\hline Serial no. & Factors & Values & Level & Contribution \\
\hline 1 & $\mathrm{pH}$ & 6 & 2 & 0.85 \\
2 & $\mathrm{LB}(\% \mathrm{w} / \mathrm{w})$ & 20 & 3 & 4.47 \\
3 & glucose $\left(\mathrm{g} \mathrm{L}^{-1}\right)$ & 10 & 2 & 2.76 \\
4 & yeast extract $\left(\mathrm{g} \mathrm{L}^{-1}\right)$ & 6 & 3 & 1.35 \\
5 & peptone $\left(\mathrm{g} \mathrm{L}^{-1}\right)$ & 15 & 3 & 1.06 \\
6 & $\mathrm{KH}_{2} \mathrm{PO}_{4}\left(\mathrm{~g} \mathrm{~L}^{-1}\right)$ & 3 & 3 & 0.39 \\
7 & $\mathrm{MgSO}_{4} \cdot 7 \mathrm{H}_{2} \mathrm{O}\left(\mathrm{g} \mathrm{L}^{-1}\right)$ & 0.5 & 1 & 0.53 \\
8 & $\mathrm{MnSO}_{4} \cdot \mathrm{H}_{2} \mathrm{O}\left(\mathrm{g} \mathrm{L}^{-1}\right)$ & 0.1 & 2 & 0.47 \\
\hline
\end{tabular}

Total contribution from all factors $=11.88$; Current grand average performance $=18.49 ;$ Expected result at optimum conditions $=$ 30.37 
Table 6: Results of confirmation experiment

\begin{tabular}{lccc}
\hline & $\begin{array}{c}\text { Predicted } \\
\text { value }\end{array}$ & $\begin{array}{c}\text { Experimental } \\
\text { value }\end{array}$ & Percent \\
& $\mathrm{A}_{2} \mathrm{~B}_{3} \mathrm{C}_{2} \mathrm{D}_{3} \mathrm{E}_{3} \mathrm{~F}_{3} \mathrm{G}_{1} \mathrm{H}_{2}$ & $\mathrm{~A}_{2} \mathrm{~B}_{3} \mathrm{C}_{2} \mathrm{D}_{3} \mathrm{E}_{3} \mathrm{~F}_{3} \mathrm{G}_{1} \mathrm{H}_{2}$ & \\
\hline Optimal level & 30.37 & 29.15 & 4.02 \\
Laccase activity $\mathrm{U} \mathrm{L}^{-1}$ & $\mathrm{M}$ & & \\
\hline
\end{tabular}

Stajić et al. ${ }^{39}$ which observed the highest levels of laccase activity under SSF conditions of grapevine sawdust after 10 days of cultivation with P. ostreatus strain No. 493 reached $2144.6 \pm 57.8 \mathrm{U} \mathrm{L}^{-1}$.

\section{Conclusion}

The level of laccase activity produced by $P$. ostreatus in WB SSF was significantly influenced by LB and glucose content. The higher levels of laccase activity (30.37 $\mathrm{U} \mathrm{g} \mathrm{g}^{-1}$ dry wt.) could be achieved with obtained culture conditions optimization: $\mathrm{pH}$ (6); LB (20\%); glucose $\left(10 \mathrm{~g} \mathrm{~L}^{-1}\right)$; yeast extract $\left(6 \mathrm{~g} \mathrm{~L}^{-1}\right)$; peptone $\left(15 \mathrm{~g} \mathrm{~L}^{-1}\right)$; $\mathrm{KH}_{2} \mathrm{PO}_{4}\left(3 \mathrm{~g} \mathrm{~L}^{-1}\right) ; \mathrm{MgSO}_{4} \cdot 7 \mathrm{H}_{2} \mathrm{O}\left(0.5 \mathrm{~g} \mathrm{~L}^{-1}\right)$ and $\mathrm{MnSO}_{4}$ - $\mathrm{H}_{2} \mathrm{O}\left(0.1 \mathrm{~g} \mathrm{~L}^{-1}\right)$. Experimentally, the maximum laccase activity of $29.15 \mathrm{U} \mathrm{g}^{-1}$ dry wt. was produced. The maximum laccase production was obtained after 8 days of incubation using SSF and static conditions at $28^{\circ} \mathrm{C}$.

Taguchi design was successfully applied to test the relative importance of medium components on laccase production. Taguchi methodology provided a systematic and efficient mathematical approach to understanding complex laccase production process for optimization of optimum design parameters, through a few well-defined experimental sets only.

In addition, enzyme production under SSF offers an advantage in minimizing production cost and maximizing mycelium growth rate, because the maximum amount of laccase can be obtained through use of agro-industrial waste such as WB and LB.

\section{Acknowledgements}

The authors would like to thank the Public Agency of the Slovenia for the promotion of Entrepreneurship, Innovation, Development, investment and Tourisms (SPIRIT Slovenia) for the financial support through Grant PMR-08/55.

\section{Reference}

1. A. M. Mayer, R. C. Staples, Phytochemistry, 2002, 60, 551565. http://dx.doi.org/10.1016/S0031-9422(02)00171-1

2. C. M Rivera-Hoyos, E.D. Morales-Álvarez, R. A. Poutou-
Piñales, A. M Pedroza-Rodríguez, R. Rodríguez-Vázquez, J. M. Delgado-Boada, Fungal Biol. Rev., 2013, 27, 67-82.

3. S. S. Desai, C. Nityanand, Asian J. Biotechnol., 2011, 3, 98 124. http://dx.doi.org/10.1016/j.fbr.2013.07.001

4. R. Tinoco, A. Acevedo, E. Galindo, L. Serrano-Carreón, J. Ind. Microbiol. Biotechnol., 2010, 38, 531-540. http://dx.doi.org/10.1007/s10295-010-0797-3

5. H. Hou, J. Zhou, J. Wang, C. Du, B. Yan, Process Biochem., 2004, 39, 1415-1419. http://dx.doi.org/10.1016/S0032-9592(03)00267-X

6. K. K. Prasad, S. V Mohan, R. S. Rao, B. R. Pati, P. N. Sarma, Biochem. Eng. J, 2005, 24, 17-26. http://dx.doi.org/10.1016/j.bej.2005.01.019

7. S Kurt, S. Buyukalaca, Bioresour. Technol., 2010, 101, 3164-3169. http://dx.doi.org/10.1016/j.biortech.2009.12.011

8. R. Tinoco-Valencia, C. Gómez-Cruz, E. Galindo, L. Serrano-Carreón, J. Biotechnol., 2014, 177, 67-73. http://dx.doi.org/10.1016/j.jbiotec.2014.02.013

9. A. I. El-Batal, N. M. ElKenawy, A. S. Yassin, M. A. Amin, Biotechnol. Rep., 2015, 5, 31-39. http://dx.doi.org/10.1016/j.btre.2014.11.001

10. G Palmieri, P. Giardina, C. Bianco, B. Fontanella, G. Sannia, Appl. Environ. Microbiol., 2000, 66, 920-924. http://dx.doi.org/10.1128/AEM.66.3.920-924.2000

11. M. Lorenzo, D. Moldes, S. Rodríguez Couto, A. Sanromán, Bioresour. Technol., 2002, 82, 109-113. http://dx.doi.org/10.1016/S0960-8524(01)00176-6

12. V. Lettera, C. Del Vecchio, A. Piscitelli, G. Sannia, C. $R$. Biol., 2011, 334, 781-788. http://dx.doi.org/10.1016/j.crvi.2011.06.001

13. A. Piscitelli, P. Giardina, V. Lettera, C. Pezzella, G. Sannia, V. Faraco, Curr. Genomics, 2011, 12, 104-112. http://dx.doi.org/10.2174/138920211795564331

14. I. Membrillo, C. Sánchez, M. Meneses, E. Favela, O. Loera, Bioresour. Technol., 2008, 99, 7842-7847. http://dx.doi.org/10.1016/j.biortech.2008.01.083

15. S. G. Karp, V. Faraco, A. Amore, L. A. J. Letti, V. Thomaz Soccol, C. R. Soccol, BioMed Res. Int., 2015, Article ID 181204.

16. L. Liu, Z. Lin, T. Zheng, L. Lin, C. Zheng, Z. Lin, S. Wang, Z. Wang, Enzyme Microb. Technol., 2009, 44, 426-433. http://dx.doi.org/10.1016/j.enzmictec.2009.02.008

17. A. Parenti, E. Muguerza, A. Redin Iroz, A. Omarini, E. Conde, M. Alfaro, R. Castanera, F. Santoyo, L. Ramírez, A. G. Pisabarro, Bioresour. Technol., 2013, 133, 142-149. http://dx.doi.org/10.1016/j.biortech.2013.01.072 
18. S. R. Couto, M. Gundýìn, M. Lorenzo, M. Á Sanromán, Process Biochem., 2002, 38, 249-255. http://dx.doi.org/10.1016/S0032-9592(02)00087-0

19. X. Liming, S. Xueliang, Bioresour. Technol., 2004, 91, 259262. http://dx.doi.org/10.1016/S0960-8524(03)00195-0

20. H. Mo, X. Zhang, Z. Li, Process Biochem., 2004, 39, 1293 1297. http://dx.doi.org/10.1016/S0032-9592(03)00291-7

21. A. Pandey, C. R. Soccol, P. Nigam, V. T. Soccol, Bioresour. Technol., 2000, 74, 69-80. http://dx.doi.org/10.1016/S0960-8524(99)00142-X

22. F. Gassara, S. K. Brar, R. D. Tyagi, M. Verma, R. Y. Surampalli, Biochem. Eng. J., 2010, 49, 388-394. http://dx.doi.org/10.1016/j.bej.2010.01.015

23. R. K. Roy: Design of Experiments Using The Taguchi Approach: 16 Steps to Product and Process Improvement, John Wiley \& Sons, New York, 2001.

24. G. Taguchi, S. Chowdhury, Y. Wu: Taguchi's Quality Engineering Handbook, John Wiley \& Sons, Hoboken, 2005.

25. D. C. Montgomery: Design and Analysis of Experiments. John Wiley \& Sons, New York, 2005.

26. A. Mishra, S. Kumar, Process Biochem., 2007, 42, 681-685. http://dx.doi.org/10.1016/j.procbio.2006.09.022

27. K. P. Singh, P. Singh, Int. J. Adv. Sci. Tech. Res., 2014, 4, 695-705.

28. I. S. Rana, A. S. Rana, Adv. Biotechnol., 2011, 11, 10-14.

29. N. Mikiashvili, S. P. Wasser, E. Nevo, V. Elisashvili, World J. Microbiol. Biotechnol., 2006, 22, 999-1002.

http://dx.doi.org/10.1007/s11274-006-9132-6
30. R. Periasamy, T. Palvannan, J. Basic Microbiol., 2010, 50, 548-556. http://dx.doi.org/10.1002/jobm.201000095

31. G. Janusz, J. Rogalski, J. Szczodrak, World J. Microbiol. Biotechnol., 2007, 23, 1459-1464. http://dx.doi.org/10.1007/s11274-007-9390-y

32. S. A. Moharib, T. M. Abdel-Rahman, T. A.-M. Moussa, R. S. Yehia, Electron. J. Pol. Agric. Univ., 2011, 14, 10.

33. E. A. Adebayo, D. Martinez-Carrera, Afr. J. Biotechnol., 2015, 14, 52-67. http://dx.doi.org/10.5897/AJB2014.14249

34. S. G. Karp, V. Faraco, A. Amore, L. Birolo, C. Giangrande, V. T. Soccol, A. Pandey, C. R. Soccol, Bioresour. Technol., 2012, 114, 735-739. http://dx.doi.org/10.1016/j.biortech.2012.03.058

35. A. M. Barbosa, R. F. H. Dekker, G. E. S. Hardy, Lett. Appl. Microbiol., 1996, 23, 93-96. http://dx.doi.org/10.1111/j.1472-765X.1996.tb00038.x

36. H. Ronne, Trends Genet., 1995, 11, 12-17. http://dx.doi.org/10.1016/S0168-9525(00)88980-5

37. D. Iandolo, A. Piscitelli, G. Sannia, V. Faraco, Appl. Biochem. Biotechnol, 2011, 163, 40-51. http://dx.doi.org/10.1007/s12010-010-9014-0

38. O. S. Isikhuemhen, N. A. Mikiashvilli, J. Ind. Microbiol. Biotechnol., 2009, 36, 1353-1362. http://dx.doi.org/10.1007/s10295-009-0620-1

39. M. Stajić, L. Persky, D. Friesem, Y.Hadar, S. P. Wasser, E. Nevo, J. Vukojević, Enzyme Microb. Technol., 2006, 38, 6573. http://dx.doi.org/10.1016/j.enzmictec.2005.03.026

\section{Povzetek}

Namen tega dela je bilo povečanje proizvodnje lakaz glive Pleurotus ostreatus PLAB z optimizacijo gojitvenega medija trdnega gojišča. Povečane aktivnosti lakaz smo pridobili s pomočjo načrtovanja eksperimenta po Taguchi ortogonalni matriki. Izbrali smo sedem faktorjev, od teh so bile vrednosti lignoceluloze, glukoze, kvasnega ekstrakta, peptona, $\mathrm{KH}_{2} \mathrm{PO}_{4}, \mathrm{MgSO}_{4} \cdot 7 \mathrm{H}_{2} \mathrm{O}$ in $\mathrm{MnSO}_{4} \cdot \mathrm{H}_{2} \mathrm{O}$ izbrane na treh nivojih in vrednosti $\mathrm{pH}$ na dveh nivojih. Za načrtovanje eksperimenta smo izbrali predlagano ortogonalno matriko L18 $\left(2^{1} \times 3^{7}\right)$ in programsko opremo Minitab 17. Analiza rezultatov izvedenega eksperimenta je pokazala, da sta imali lignoceluloza $(20 \%)$ in glukoza $\left(10 \mathrm{~g} \mathrm{~L}^{-1}\right)$ pozitivni učinek, medtem ko $\mathrm{KH}_{2} \mathrm{PO}_{4}, \mathrm{MgSO}_{4} \cdot 7 \mathrm{H}_{2} \mathrm{O}$ in $\mathrm{MnSO}_{4} \cdot \mathrm{H}_{2} \mathrm{O}$ niso imeli pomembnega vpliva na produkcijo lakaz. Analiza rezultatov Taguchi ortogonalne matrike je pokazala, da so $\mathrm{pH} 6$, lignoceluloza $20 \%$, glukoza $10 \mathrm{~g} \mathrm{~L}^{-1}$, kvasni ekstrakt $6 \mathrm{~g} \mathrm{~L}^{-1}$, pepton $15 \mathrm{~g} \mathrm{~L}^{-1}, \mathrm{KH}_{2} \mathrm{PO}_{4} 3 \mathrm{~g} \mathrm{~L}^{-1}, \mathrm{MgSO}_{4} \cdot 7 \mathrm{H}_{2} \mathrm{O} 0,5 \mathrm{~g} \mathrm{~L}^{-1}$ in $\mathrm{MnSO}_{4} \cdot \mathrm{H}_{2} \mathrm{O} 0,1 \mathrm{~g} \mathrm{~L}^{-1}$ optimalni pogoji za maksimalno produkcijo lakaz. Po modelu je bila napovedana produkcija lakaz $30,37 \mathrm{U} \mathrm{g}^{-1}$ suhe snovi pri optimalnih pogojih, eksperimentalno smo dosegli aktivnost lakaz $29,15 \mathrm{U} \mathrm{g}^{-1}$ suhe snovi, kar je v skladu s napovedano vrednostjo po modelu. 